\title{
Rethinking the Employability of International Graduate Migrants: Reflections on the experiences of Zimbabweans with degrees from England
}

\author{
Simon McGrath ${ }^{\mathrm{a}}$, Roda Madziva ${ }^{\mathrm{b}}$ and Juliet Thondhlana ${ }^{\mathrm{a}}$ \\ ${ }^{a}$ School of Education, ${ }^{b}$ School of Sociology and Social Policy, University of Nottingham
}

\begin{abstract}
The last decade has seen the rise of literatures that have focused on the rapid expansion of the numbers of international students in higher education globally and the growing policy discourse around improving graduate employability. However, both, inevitably, have limitations. Together, they tend to homogenise international learners and see them narrowly as simply economic actors. More recently, however, there have been signs of important new developments in both literatures, drawing on interactive employability and capability accounts that stress both agency and structure in more satisfactory ways. We seek to further the development of an account that bridges the new wave of student mobility research and the capability-employability account. In doing so, we offer two further elements to the literature. First, we aim to bridge the gap between international higher education accounts and those of migration and diasporic studies. Second, we deliberately focus on a group that is marginal to the mainstream discourse but who are migrants that have engaged in international higher education in order to improve their labour market prospects, amongst other motivations. We do this through examining the stories of five Zimbabweans who embarked on additional higher educational studies in England after migrating to the country. Through this unique approach, we offer an important new perspective on how the debates on international higher education, employability and migration can be taken forward through closer articulation between these accounts.
\end{abstract}

\section{Introduction}

The last decade has seen the rise of literatures that have focused on the rapid expansion of the numbers of international students in higher education globally and the growing policy discourse around improving graduate employability. However, both, inevitably, have limitations. Together, they tend to homogenise international learners into an ideal student who is young and who is attracted to international higher education (whether through migration, enrolment at an international branch campus or learning online) as a human capital investment. Equally, much of the discourse and literature around 'graduate employability' tends in the same narrow human capital and employability direction and focus on what institutions and nations need to do to capture a market for such learners/graduates.

More recently, however, there have been signs of important new developments in both literatures. In the international higher education literature, an approach is emerging that focuses far more on the learner as an individual embarked on a pathway to future employment, which problematises conventional employability accounts (e.g., Brooks and Waters 2013; Li 2013). In the realm of graduate employability, there is a new interest in interactive employability and capability (e.g., Hinchcliffe 2013), which mirrors existing debates in further education and labour market studies.

In this paper we seek to further the development of an account that bridges the new wave of student mobility research and the capability-employability account. In doing so, we offer two further elements to the literature. First, we aim to build a further bridge between international 
higher education accounts and migration and diasporic studies. Second, we deliberately focus on a group that is marginal to the mainstream discourse but who, nonetheless, are migrants that have engaged in international higher education.

In what follows we will examine the stories of five Zimbabweans who embarked on additional higher educational studies in England after migrating to the country. Through this original approach, we offer a new perspective on how the debates on international higher education, employability and migration can be taken forward through closer articulation between these accounts.

\section{International higher education, employability and migration}

There has been a rapid expansion of the literature on international higher education, mirroring the growth of the phenomenon. Initially, research focused primarily on national policies and institutional practices (e.g., de Wit 2002; Knight 2004; Luijten-Lub, Van der Wende and Huisman 2005; Altbach and Knight 2007). The little research in this era that focused on students concentrated on what attracted students to enrol and what maintained their customer satisfaction (e.g., Mehtap-Smadi and Hashemipour 2011; Wilkins, Balakrishnan and Huisman 2012). This approach is very much from the perspective of university planners, who are the principal assumed audience of the emerging literature. It implicitly assumes a relatively unproblematic relationship between getting an international degree and achieving employability in a graduate job that is located in a wider human capital approach.

However, some recent accounts, such as those of Brooks and Waters (2013), Li (2013) and Streitwieser (2014), have developed a richer story of the student as a more complex actor. Here we follow Brooks and Waters $(2013,163)$, who suggest 'the need for a people-centred perspective on student mobility'. Like them, we attempt 'to look beyond crude economic and political assessments ... towards understanding the often highly personal and always social reasons' involved in migrants' accessing higher education. This is not to deny the importance of international flows of highly skilled labour for national economies; of international student income for universities; or economic rationales for individual migration. Rather, it is to insist that these need to be understood as part of a wider set of rationales for, and meanings of, international student participation in higher education.

This new student mobility literature links well with critical accounts regarding employability. The conventional approach to employability, particularly in England, emerged in response to a decline of industrial production necessitating a new form of preparation for the world-ofwork; the Neoliberal ascendancy ending the welfare state and placing education and work at the centre of approaches to end poverty and social exclusion; and the rise of the discourses of lifelong learning and boundaryless careers. Together, these factors have led to a focus on an individual's employability, conventionally understood as their ability to gain initial employment, maintain employment, move between roles within the same organisation, obtain new employment if required and (ideally) secure suitable and sufficiently fulfilling work (Hillage and Pollard 1998).

Whilst this account remains powerful, particularly amongst policymakers and institutional planners, it has been severely critiqued by authors from a range of disciplines and traditions. Alternative readings of employability from authors such as Gazier and Houneman (1999) and McQuaid and Lindsay (2005) argue that this 'initiative employability' account reflects an Anglo-Saxon tendency to think in terms of atomistic individuals who are solely responsible for their own employability. This leads to a downplaying of labour market and other contexts 
and a denial of the responsibility of employers and politicians for influencing employment opportunities. Gazier and Houneman also note that this model of employability focuses on the immediate issue of young people getting their first job, and shows insufficient concern about the quality of that job, the likely sustainability of the employment or the prospects for future career development and progression, all of which are influenced by wider labour market and economic contexts.

Whilst this tradition insists on adding more structure to the account, authors from the capability approach have critiqued the employability orthodoxy for its weak account of agency. The central notion here is the capability for work:

not identified as the mere possibility to get an adequate wage, it focuses on the agency dimension, that is the capability to participate in society. (Bonvin and Farvaque 2006, 128).

The language of the capability approach is dense and we need to unpack briefly some of the key concepts. Capabilities are 'what a person is able to do or be' (Sen 2005, 153) and the freedom to select from these. These are distinguished from functionings: what a person actually does, the life they actually live and their achieved wellbeing (or illbeing). This distinction highlights the importance of individuals' choices and opportunities rather than only their actual achievements, a crucial point for our story. This builds on Sen's stress that 'acting freely ... [and] ... being able to choose are ... directly conducive to wellbeing' (Sen 1992, 50). The approach further distinguishes between two overlapping aspects of this important concept of freedom. First, the opportunity aspect, which is concerned with the opportunities available to people to achieve functionings. Second, the process aspect, which is concerned with the agency and the processes of choice involved (Sen 1985).

More recently, there has been a growing merger of a capability-employability account that stresses both agency and structure, seeing them as intertwined (e.g., Bonvin and Galster 2010; Hollywood et al. 2012; De Jaeghere and Baxter 2014; McGrath and Powell 2015). These authors' view that work is vital to human development leads them to reject the assumption that any job will do; whilst their belief in the primacy of human development means that they see economic benefit as a means to the greater goal of human wellbeing.

This approach makes clear that processes of trying to achieve this ultimate goal are complex. De Jaeghere and Baxter (2014) focus on the crucial and challenging moments when individuals try to convert initial endowments (in this case prior experience and qualifications) into capabilities, and capabilities into functionings. Powell and McGrath (2014) return to the question of freedom by deploying Appadurai's notion of the 'capacity to aspire':

The capacity to aspire provides an ethical horizon within which more concrete capabilities can be given meaning, substance and sustainability. Conversely, the exercise and nurture of these capabilities verifies and authorises the capacity to aspire and moves it away from wishful thinking to thoughtful wishing. Freedom, the anchoring good in Sen's approach to capabilities and development, has no lasting meaning apart from a collective, dense, and supple horizon of hopes and wants. Absent such a horizon, freedom descends to choice, rational or otherwise, informed or not. (Appadurai 2004, 82)

This is particularly important for, as Appadurai argues, poverty tends to result in 'more brittle horizon of aspirations' (Appadurai 2004, 69) for individuals and communities so that they cannot imagine, let alone achieve, what might be possible in other circumstances.

Through drawing on these theoretical resources, we see our informants not simply as consumers of international higher education and investors in their own human capital, but as 
multidimensional human beings with complex and fallible life projects that are shaped both by their agency and by their experiences and perceptions of structure (cf. Powell and McGrath 2014). This leads to far more complex patterns of higher education and labour market participation that are shaped both by individual agency and by structural effects such as the impact of cultural approaches to gender relations; the contradictory effects of ethnic social networks; and the challenges of operating in a national labour market as a migrant from an ethnic minority. Such an approach does not deny or ignore the importance of economic rationales but seeks to place them within a wider set of considerations and aspirations.

Although it is at the intersection of the new student mobility and capability-employment literatures that this paper is primarily located, we also want to insist on the importance of drawing on the insights of migration and diasporic studies for thinking about international students (cf. Amazan 2014). In particular, we are influenced by research that acknowledges the complex and contradictory effects that migrants' ethnic social networks have on their labour market trajectories. There is a large literature that explains how migrants' social networks facilitate international migration as new migrants and refugees often move to international destinations where there is an already existing concentration of compatriots and/or established ethnic communities (e.g., Massey and Espinosa 1997; Palloni et al. 2001; Poros 2001; Harvey 2008). These studies show how access to social networks can facilitate successful labour market insertion. However, Vertovec notes how some such networks can lead to new migrants becoming trapped in 'a limiting ethnic niche occupation or domain' (Vertovec 2002, 5) which can lead to downward occupational trajectories.

\section{The Study}

In this paper we look at five out of a larger sample of 30 in-depth semi-structured interviews. The participants in the larger study were recruited through the social networks of Zimbabwean migrants and through snowballing. The interviews were largely chronological in structure, focusing on what the interviewees did professionally (and their lives more broadly) prior to moving to England; the circumstances of their move to England; and their experiences of work and life as migrants. Where appropriate, more directive probing was done at the end of the interview to ask about their views about the nature of employability and how this varies between the two countries.

All interviews were recorded and transcribed, and separately and then collectively analysed by three researchers from different disciplinary backgrounds (in comparative education, sociolinguistics and diasporic studies). The sampling, interview topic guide and initial analysis had not been focused on higher education experiences in England. Rather, attention had been directed to the experiences of already highly skilled migrants in navigating the English labour market (Authors 2015a and b). However, on considering the data further, the potential value of looking at those who had furthered their education after migration became apparent. Thus, the five relevant interviews were reanalysed with a strong focus on what motivated these respondents to return to studies and how they subsequently deployed this further learning. On repeat reading, the data increasingly spoke to notions from the capability approach and the data was then further reanalysed from this perspective.

In such a paper focused in great detail on individuals' stories, our own autobiographies are highly pertinent. Two of the three co-authors are Zimbabwean migrants to England; whilst the other is a former migrant to Zimbabwe. The migrant and ethnic identities shared between the two Zimbabwean interviewers and the interviewees are apparent in the transcripts. In 
analysing the interviewees, the team sought to bring these to mind explicitly through creating a dialogue between the two African female and one European male authors. Their differentiated experiences of Zimbabwean and English cultures and workplaces and their differing experiences of how race and gender shaped these were central themes of team analytical meetings.

The data we draw upon is a set of accounts generated by individual respondents in the specific context of being asked questions about their education and employment experiences in England. The framing of the interviews necessarily will have had an effect on how they constructed their narratives. How they remember and how they present the past necessarily must be selective and we have no way of knowing any truth behind the interviews. Interviews exist in time and space and so does their analysis. Both the interviews and the analysis took place in England, but drew upon the diasporic settings of both researched and researchers. Interviews took place in late 2013 and early 2014, with this particular analysis taking place in mid-2014. This was a point at which the situation in Zimbabwe was relatively stable and Zimbabweans were not a key focus of rising English anti-immigrant rhetoric. Thus, it was a relatively neutral moment at which to be conducting this research. Nonetheless, we are acutely aware of the above limitations and of the dangers of taking interview narratives as more than stories.

The current literature has tended to look for patterns in student and graduate experiences and has focused on the mean and the typical. However, here we are deliberately looking for exceptions, contradictions and complexities. Moreover, we assert the moral, emotional and analytical power of the individual case over the tendency to reduce individuals to data points in analytical categories. This necessarily limits our ambition in terms of offering a new theorisation of the field, though the theoretical resources we do mobilise do point to a potential alternative theorisation of the field.

\section{The Context - Zimbabwean Migrants to England}

Zimbabwean independence in 1980 facilitated upward mobility among black Zimbabweans. A new successful middle class emerged that adopted much of the lifestyle of the colonial elite and who viewed it as largely the way of life that was appropriate for members of the professional class. Education, already well-valued and a major source of unrest under white settler rule, was accorded great value both as a process of human capital investment and as key to entry into an elite lifestyle (McGregor 2008). Possessing a degree virtually guaranteed a salary that was unimaginable to rural Zimbabweans but also an accompanying package that might comprise a company car; payment of fees for elite private schools; a subsidised mortgage; membership of top-class sports club; and even, on occasion, paid family holidays and employer-supplied domestic workers.

However, this golden age proved shortlived. The economic downturn of the mid-1990s reduced the largesse of employers' compensation schemes and led to rationing, queuing and shortages of essential commodities. It also produced increasing contestation of the postindependence political settlement. The increasing hardships of living in Zimbabwe led many Zimbabweans to migrate. For many this resulted in a precarious existence in South African townships and informal settlements, and the threat of xenophobic attacks. However, for the professional elite there seemed to be the opportunity of sustaining their acquired status and lifestyle through schemes such as the UK Highly Skilled Migrant Programme. Knowing that their lifestyles were modelled on those of a British colonial elite, there was widespread 
confidence that they could take their British style degrees and move into similar jobs and lifestyles in Britain (cf. Authors 2015a).

\section{Five stories; five windows on the employability of international migrants /students}

To emphasise the point that each individual has their own unique story, we will resist for a little longer the typical academic move to look for patterns across informants and will provide five, inevitably simplified, stories of our informants for this paper. These are deliberately presented as linear narratives to highlight the lived experiences contained in them, rather than imposing a theoretical framework upon them at this point.

\section{Nyaradzo (All names are pseudonyms)}

Much of the attention given to Zimbabweans in England has focused on the large numbers who have found employment in the care home sector: as 'British bottom cleaners' according to the political rhetoric of ZANU PF. Across our larger sample, a number of women and men had ended up in this setting, even though they were all graduates. Nhamo (below) was one of those who moved on from there, back into her own education profession in her case. Nyaradzo, however, is an example of a healthcare professional who found both fulfilment and professional development through her time in the care home sector.

Nyaradzo first moved to England at the start of the 1990s to be a Nursing undergraduate. Ironically, this was as she had not got the grades to get into the University of Zimbabwe. The move was facilitated by her relatively privileged background, which included family members in England. Although nursing was not her first choice of a career, she recalls realising early on in her studies that this was a good fit for her own growing identity as a caring professional. At this stage, she was simply taking the opportunity to get a good quality international professional education in order to equip her better for work and life at home. Indeed, after securing her qualification in 1995, she moved back to Zimbabwe, to get married.

all my family, the people that I love were in Zimbabwe, so it made sense really to get married there.

However, the next few years saw a tension between her desire to develop a life and career in Zimbabwe and the sense that there were more professional education opportunities in England. Thus, she moved back and forth between the two, gaining a further qualification in England in Health Service Management and becoming the youngest tutor at the leading Zimbabwean School of Nursing. She found herself pulled two ways. Her latest (third) move to England was ostensibly to take up a post as a deputy home manager for a nursing home for people with learning disabilities. However, it was primarily a staging post for her further career plans.

The account she gives of her time in the care sector is one of an ambitious professional who is also a lifelong learner, excited by the possibilities and opportunities that exist within the system. Her employers sent her to be an NVQ assessor so that she could supervise the career development of her staff. She then persuaded them to support her to do a Certificate in Counselling. This led her to a Master's degree and to employment by the NHS as a counsellor. Even then her drive to learn more in order to advance her career has continued: 
cognitive behaviour therapy is sort of the in thing these days, ... And as a counsellor, there came an opportunity that ... I could do this course and still be paid my salary, and they would pay for the course ... and now I'm working as a cognitive behaviour therapist for the NHS.

She has now started her own counselling practice alongside her formal employment. A confidence in herself and how to navigate the English system comes strongly through the transcript. She has constantly worked to develop herself but following paths that made intuitive sense because they felt authentic to whom she considers herself to be. As she stresses:

you can't maximise your potential and reach your goals without actually knowing who you are.

Her story is one of human capital investment but this alone is too narrow an explanation of someone who has a life project of being a successful caring professional both in terms of her vision of service to others and her aspiration to professional status.

my passion was always in the caring industry, I always wanted to help people and by helping people, I wanted to work with people and kind of support people together, you know. So nursing was a great opportunity for me to do that, but there came a time when I realised that there was more to it. I just felt having gone into management, ... it wasn't really the thing that I wanted, it was more administrative, ... So it was then that I really started thinking about how can I make a difference in people's lives where I have an opportunity to talk to them? And that's when I sort of started thinking about going into counselling.

She is also noteworthy as someone who has had successful careers both at home and in England, and appears to have been able to deploy both human and social capital effectively in both settings, although an exploration of this is beyond the scope of this paper.

\section{Nhamo}

Nhamo is a teacher, with a Zimbabwean Bachelor's degree, who arrived in England in 2002 following her husband. She found herself blocked by non-recognition of existing professional qualifications. Whilst she sees herself as a highly competent and experienced teacher, neither her qualifications nor experience have been fully recognised in England and she got stuck in supply teaching. After three years, she identified an attractive career change into social work, which would fulfil her desire to get recognised and paid as a professional. Her interview suggests that the frustration of lack of professional autonomy and recognition as a supply teacher was the primary driver here rather than a more narrow human capital investment in a further degree to gain a higher income or any real aspiration to be a social worker, a profession she is strikingly silent about in her interview.

as a supply teacher I don't do much work I don't plan, I don't scheme, I don't do nothing I just wake up in the morning, eight o'clock, and ... I go straight into a school and meet the children, there is work planned for you already. ... You are more of a prefect in a school, in a classroom. You go in there and the only thing you use is your control of the children, your skills and your motivation and how you manage to control the class that it doesn't make a noise

However, most strongly, Nhamo's story reminds us that life plans are not only fallible but are fragile. Her experience of learning, working and living in England has been punctuated by the personal tragedies: 
So I enrolled with the University ... in 2005 ... And then when I was in my second year, 2006, my husband died.

The situation was made worse by cold bureaucratic rules. Having been on a visa that made her a dependant of her husband, Nhamo's status as a student was compromised. When she did get her visa sorted out and was about to return to her studies again, another personal tragedy intervened:

So I applied and they said, 'Okay you can start in March where you left off you can join that group there then you can continue the remaining one and a half years', which I had done. But the tragedy is again my other son, who was left in Zimbabwe, died.

Nhamo clearly has been a dutiful aspirant British resident who, at least on one level, has embraced the dictates of human capital theory and the employability discourse. However, towards the end of her interview she strikes a radically different note:

And I looked at my clock and said, 'I am 55. I've been studying all my life', since I got married I never enjoyed my husband, I never enjoyed my children I've been studying, I'm not going to do that I've got the house with the compensation we got from the accident.

Here we have a glimpse of a willingness to defy the orthodox view of the duty to become more employable in favour of an alternative conception of what is seen as constituting a good life.

\section{Pafunge}

Pafunge qualified as a forestry officer in Zimbabwe before studying part-time for a BSc in Geography and Environmental Studies in Zimbabwe. She came to England to follow her husband, only arriving three years after him in 2005 due to visa issues.

Several Zimbabwean migrants in our larger sample, particularly health workers and engineers, found it easy to get initial employment in their own professional area due to acceptance of their existing professional qualifications and experience as valid. However, in the less regulated environmental sector, Pafunge struggled to find employment, as neither her qualifications nor her experience appeared to have value to English employers:

I applied for a job once in this organisation that does some environmental activities. I was called for an interview which, which was fine, but people who have got qualifications from here stand a better chance from those who have got qualifications from Zimbabwe. That's what I saw from that particular post. And also because I didn't have any of the experience of working within the UK setting, I didn't really stand a better chance ... here I think it's mainly experience, experience, experience

Like many Zimbabwean, and other African migrants, she drifted into the call centre industry. However, this did not satisfy her sense of who she was.

I found I've wasted about four years, ... it's time wasted, you know, when you could have been doing valuable things. ... What skill am I getting just talking to someone over the phone? What skill does that impart?

As a result she started to look for Master's courses that could help her get into professional employment, conscious that, whilst English professional work experience was the most 
important thing for her career; she could not even get this and so a further, English qualification would be her first step to professional employability in her new home. Both her decision to study and her initial choice of programme to apply to were heavily influenced by her ethnic networks, as well as the realities of which programmes were easiest to access, particularly because of the availability of funding (as in Nhamo's case):

most of the Zimbabweans I am coming in contact with have taken up studies, and it's more like okay everyone is now studying, everyone is now studying. Usually I think most people I have been in touch with or talk to, they've either done nursing or they've gone into social work. ... you don't self-fund, they're actually funded by the government. So initially I thought okay ... just to get out of this call centre thing and to kind of go back to school, let me do social work as well.

However, Pafunge's initial failure to secure a place for a Master of Social Work programme at her two local universities caused her to reconsider what was her life plan. Instead of deciding to look slightly further afield for an MSW place, which would have been feasible given where she was living, she spent time reflecting on what she actually wanted to do careerwise. This led her to the conclusion that the best way forward was to take her existing environmental background in a new direction that also drew on the public health focus of much of the Zimbabwean diaspora:

in the meantime I was also looking, I was thinking, 'environmental health, that could be something interesting', and ... just looking at the ... description of the, of the Degree, I was thinking, 'I think I would be better suited here. Fine, this is more ... it's actually making my heart, you know excited'. As I was looking at social work and I'm thinking, 'ah, this might not be for me, yes I'll just go and do it because people are just doing it, you know, for survival'.

Whilst in the narrowest sense of economic rationality, doing Social Work would have offered the best return on investment, and would have minimised initial financial risk, her story makes it clear that her initial setback in following this route led to a more complex calculation being made regarding what she actually wanted to do with her life.

Pafunge's interview also illustrated another factor in the calculations of some migrants. Rather than talking the language of the dominant literature of the globally employable graduate, hers is more a typical account of the migrant aware of political dynamics both in an increasingly unwelcoming host country and in a home where political change can still be imagined:

things are getting tough within the UK and I need to be seen to be doing something because if things change, if we decide okay we're going back to Zimbabwe, I need to go back with education that is higher than what I had and also hoping that, you know, people ... recognise the international degrees.

\section{Tashinga}

Tashinga's move to England was motivated both by ambition and worries about the future of his country. Already during his studies for an MSc in Sociology at the University of Zimbabwe, he was working as a government research officer, and on completion of his course, he had a PhD place on offer at the University of Zimbabwe. Yet, he was worried both about his ability to self-fund his $\mathrm{PhD}$ in a declining economy and the longer-term prospects in the country. Thus he planned a way out: 
working as a research officer, it was a high-paying job. So I saw it as an opportunity to buy the ticket then. So I bought my ticket and came to the UK because I thought I wanted to do a $\mathrm{PhD}$ but there were no funded $\mathrm{PhDs}$ at the University of Zimbabwe.

However, his plans were fallible in that he did not realise the obstacles to being in a position to get a funded doctoral place in England or the challenges involved in getting himself to the point where he could self-fund his studies. Although he arrived on a student visa, it was quickly apparent that paid work was what he needed first. However, his visa status was a disadvantage and he ended up working in a warehouse, alongside many other migrants from Zimbabwe, and elsewhere in Africa.

He describes powerfully the effects of the 'warehouse mentality' and how this particular manifestation of ethnic networking undermined his aspirations:

the kind of social circles that I got entangled in the UK, it doesn't really help to get an education. We are here to make money, so my focus changed from an academic focus, to looking for money. ... 'So and so has got a degree, but they are working in the warehouse. So and so has got his Master's.' So it really sort of discouraged me in a big way ... that drive to go to education, ... It had sort of died in me. ... Even when you work in a warehouse, the kind of money that you earn is almost similar to the one that an educated person can earn. So it dampened my spirit and I abandoned these academic things.

Like Pafunge, Tashinga was also very aware of the insecurity of being a migrant, particularly from an unstable country. Whereas Pafunge was determined to study further in case she was able or required to return home, Tashinga tells of the warehouse view of this context:

Back then people were saying, 'If Mugabe goes, probably we will all be sent back'. So the thrust then I think it was to say, 'Let's get money, as much as we can. Let's accumulate as much as we can and when we are pushed out, at least we have something.' So you find out that no one was really bothered about advancing their education. Even people like myself who had come to pursue an academic career, when you came over here you discover my life is very insecure. Any time I can just be deported. So I think that insecurity. It played a part in discouraging us from pursuing other career goals as well

However, there came a point where Tashinga reclaimed his agency and 'capacity to aspire'. He recalls,

I began to tell myself that I can do something better. So I applied for a permanent job at the City Council and I got it.

From there, he applied internally for a better job. This change of workplace and occupational status also had an important effect on his social networks:

my social circles also changed as well. ... when I saw my other friends as well who were doing something different and you could tell with the kind of things that they were doing, the opportunities that those kind of jobs are offering them or even the career things that they were doing, it changed my focus to my original plans that let me go back to school and do something that I've always desired to do.

He then enrolled part-time for a Master's in Social Research, realising that this was an important step in getting a PhD place. This led him to work as a researcher first for a national NGO and then for a university. However, the fallibility of this route was then revealed when 
the team could not secure any further long term grant capture and he has found himself as one of the many researchers on the periphery of the HE system, getting scraps of short-term contract research work. His understanding of the sector is that he must now get his $\mathrm{PhD}$ to have any chance of becoming a core academic worker. He is applying for places and funding. As with other cases, there clearly is an element of economic rationality here. However, there is a strong sense throughout our interview with him that it is the $\mathrm{PhD}$ that is the strongest motivation throughout and that this is not simply about the instrumental benefits that the PhD brings.

\section{Garikai}

Garikai is an accountant. He got a Diploma at Harare Polytechnic before moving to South Africa where he got an Advanced Diploma part-time and started a BCom before migrating to England. As he tells it, he already had a good job in South Africa but came to England on a whim because a friend invited him over:

I just told my mother, I told my brothers and my family, 'You know what? I want to go to the UK just for two weeks, just two weeks. I'll take leave from work, just two or three weeks out, go to the UK and to see how it is. I'll be back.' And I'm here, ten years on!

Arriving on a whim on a holiday visa, he was advised to apply for asylum when he arrived and took this advice without really thinking through his future plans.

As we noted in telling Pafunge's story, some professions have easier transferability than others. Garikai came to England expecting that his accountancy qualifications and experiences would make employment easy. However, this was not the case:

So I could see myself, I could see myself getting those jobs easily, and when you look at the experience, I could say, 'I can transfer my experiences from Zimbabwe and experience of Africa, and transfer it here, ... but now what they were saying now, they say the experience which I'd got in Africa would not count, ... they just killed me completely, they demotivated me completely, they degraded me to a nobody

Having given up on his professional route, he eventually did find work as a technician working on domestic and commercial alarm systems. However, eventually, he too refound his capacity to aspire:

the resuscitation of the old person now started coming back the third year of working for this company. ... I told my boss, 'I need to go back to university'.

This led him to enrol for a BA in Accounting and Finance. This was strongly motivated by a sense of human capital investment, to be sure, but being accepted societally as a professional seems to have been uppermost in his enrolment decision.

Whilst he found his studies easy and got high grades, helped greatly by his previous qualifications and industry experience, his planning was now shown to be insufficient as he discovered that he really needed to be articled in order to pursue an accountancy career. He then realised that there was harder study and work ahead to become articled. However, getting a place proved difficult and the amount of effort required and the initial low salary seemed less attractive than getting a well-paying but low skilled job through African diasporic networks, delivering newspapers at night time: 
I got the job there and then I start to find out that it's only two hours, and two hours give me $£ 600$ a week, and where can I get $£ 600$ a week for seven days, two hours?

This seems a strong case of thinking as a rational economic actor. However, even now, the importance of being a professional has not subsided for him, although he needs to balance this with his responsibilities towards his young family. Deciding that the family cannot survive on the income he would get as an articled clerk, he is continuing to deliver newspapers whilst pursuing his professional qualifications through distance learning. Again, the sense that comes through is one of a complex and fallible human being making trying to construct a good life rather than simply investing in his human capital.

\section{Analysis}

The intention is not to develop a grand unified theory out of these five cases but to use them as pointers towards the complexity of living as a migrant and mobilising higher education as one means of achieving a better life and becoming successfully employed. Some themes that do come out of the five stories are presented, however, for their potential value to future theorisations of the nature of the intersecting concepts of international student experience and migrant employability.

Even from five cases it is apparent that motivations towards further study of this particular group of international learners are diverse and reflect complex interactions between agentic and structural elements. There is a strong sense that further study is important but it is clearly constrained and shaped by a range of factors. Study routes are limited by immigration, qualification equivalence and fees regimes. The financial costs of studying are high, both in terms of direct and opportunity costs. As a result, courses with bursaries were reported to be particularly attractive to Zimbabweans. Thus a subject such as Social Work becomes attractive because it is affordable more than because it is genuinely attractive in itself.

We will not attempt here to theorise the ways in which gender shapes decisions to study what and when, or how race and immigration status impact upon labour market outcomes. However, their effects appear to be real and substantial. For the three women in the group, marriage seems to have been a crucial factor in shaping their migration, work and study paths. Nhamo, like some in the wider interviewee group, had been profoundly influenced by her husband's view of what an appropriate career was and the need for a wife to pursue her education in order to be a better partner. However, it is important to note that marriage also appears to have been quite important to Garikai's recent sense that he needs to knuckle down to developing a career for himself. Again, this appears to be strongly shaped by a gendered discourse of responsibility. Gender effects also seem to be in play in pushing Zimbabwean female graduate migrants towards a set of further degrees and professions that are predominantly feminised and have a large migrant presence.

For some of these five, and for others in the larger sample, the constraints of the immigration regime and related regulations on study and professional equivalences were keenly felt as racialised, whatever the intentions. Equally, the labour market is also sometimes seen as a site of discrimination (Authors, forthcoming). However, for others there was a refusal to accept the victim status that could come with discrimination. Rather, there was a desire to stress their own agency. Indeed, Nyaradzo was amongst the several respondents in the wider study who noted that her Zimbabwean professional experience had made her more multiskilled than typical English counterparts. Thus, there appears to be no simple story of how 
employability translates from Zimbabwe to England: for some, qualifications and experience are portable, but not for others.

There are pointers in the stories towards the salience of arguments about the effects of intraethnic (and broader Pan-African migrant) social networks in both helping individuals to navigate the English labour market successfully and in locking them into particular segments of the labour market. We have noted feminised professions above but there is also evidence of some gravitation towards low skill labour market segments.

Recalling De Jaeghere and Baxter's stress on the importance of conversion from initial endowments to capabilities and then to functionings, it appears that there may be multiple elements of such conversions, and failures to convert, going on in these life stories. Agency is being enacted in all stories and sometimes this is being supported by employers, families and ethnic networkers in ways that allow successful conversions. Nyaradzo, for instance, appears to have a strong sense of what she values and aspires to and has found ways to actualise this to a large extent. However, other stories tell of how what is valued (e.g., professional status, experience, self-worth, being a good wife) can be undermined by structural effects and the undermining of aspirations and self-belief, a point to which we will return in a moment. The capability approach also reinforces the sense that comes through these interviews that human flourishing is not simply a matter of employability. Rather, further studies and employment are pursued for multiple reasons.

The psychological dimensions of the negative warehouse mentality amongst some African migrants are powerfully illustrated by Tashinga's tale. Yet, his story is also one of how a professional diasporic network can be highly supportive of aspirations.

The issue of aspirations appears to be one that would merit further exploration. Appadurai's 'capacity to aspire' seems to work well conceptually with the literature about intra-ethnic social networks but also with a reading of the often hostile realities of the English labour market as experienced by these migrants. Equally, his notion of the 'brittle horizon of aspirations' (Appadurai 2004, 69) that results from constrained experiences and networks has resonance. Our informants' migrant status does appear to have made their aspirations more fragile.

Nonetheless, there is also much across the interviews that talks to the resilience of aspirations to being a professional in terms of work, income and status. Potentially importantly, there is also a sense that fragile aspirations can be repaired when broken. Both Tashinga and Garikai narrate how aspirations can be 'killed' but also the possibility for their 'resuscitation'.

This notion of fragility can also be applied to their broader pursuit of wellbeing. Each of the informants is engaged in making a new life for themselves in England, based on aspirations and plans. However, these are fragile in the face of the realities of being migrants but also, most sadly in Nhamo's case, are subject to the vicissitudes of life, and death. With the exception of Nyaradzo, these informants are trying to make their way but sometimes struggle to learn the rules of what it means to be employable in England or to make the rules work for them. They talk of the insecurity of being a migrant, which leads to further calculations about employability. Whilst at home professional status and income were closely correlated, here they seem faced with a challenge of whether they should focus more on status or income. Equally, as Pafunge and Tashinga illustrate, there are different individual calculations of what is the best strategy in case of going home. Should the migrant focus on banking income (taking whatever work pays well) or banking human capital (building up qualifications)? In truth, neither they, nor we, know which is the best strategy or what the medium-term future 
of Zimbabwe is likely to be: their choices are necessarily imperfect and constructed in the complex interplay of agency and structure, and of autobiography and social norms.

Collectively, the stories have a power in their foregrounding of the psychological and deeply emotional nature of the experiences of our informants. This is something that is vital to a full understanding of employability but absent from the rather cold and clinical telling of much of the literature.

This leads on to what is both a theoretical and a methodological point, made powerfully in the capability approach, regarding the importance of hearing the complex stories of individuals and refusing the tendency to move immediately to the mean and to generalised abstraction. Before, and beyond, they are a collective construct; international learners / migrant workers are individuals and this truth needs reiterating in research and policy conversations.

\section{Conclusion}

The choice of focus on Zimbabwean highly skilled migrants returning to higher education was motivated by a concern with the limitations of the typical case of the international higher education student. The mainstream literature understandably focuses on the 'typical' international student: the young undergraduate who has progressed on the 'normal' education pathway from school to university. However, here we focus on the experiences of Zimbabwean migrants to England who studied in the country but who did so when already resident in the country. Such learners may be classified as either international or home students depending on their time in the UK and immigration status, but are part of a sizeable grouping of international higher education students who experience higher education, and who are perceived by others within it, as international students. Whilst the dominant literature on young undergraduates has increasingly acknowledged that they are not necessarily homeward-bound after their studies; the strong thrust of the literature is on their position as 'global talent', likely to return home to high status employment and /or to become 'global knowledge workers' as high skilled migrants. Yet, the group that we consider is aware more of their indefinite status as migrants in a particular location and their need to make new lives and find new livelihoods there, whilst perhaps still clinging on to the notion of returning home some day.

We have deliberately tried to present five individuals' stories of the experiences of the higher education experiences of Zimbabwean migrants to England as unique in order to make a point that it is theoretical, ethical and ontological about the importance of the human dimension of social research. We have listened to them talk about the ways in which they have sought to use a return to higher education to help them achieve their aspirations and found that such deeply personalised stories are not reducible to a simple story of pursuing higher education in order to increase employability and maximise income. Clearly there are elements of a relatively simple employability and human capital investment story in here. However, there is also much more that points towards the kinds of arguments that have been made in the interactive employability account. The atomistic individual of the initiative employability account is nowhere to be seen in these cases. Rather, a picture far more akin to that outlined by McQuaid and Lindsay (2005) seems to come into focus, in which the attributes, qualifications and motivations of the individual are only one strand of what shapes employability, and need to be understood alongside factors of health and familial responsibility; labour market segmentation; immigration law; cultural factors; etc. Equally, the tendency of the initiative employability account to construct employability as the moral 
duty of the citizen-consumer is counteracted by a sense of Bonvin and colleagues' notion about the freedom to choose a job that has personal value and, even, the right to choose not to be employed. Echoes of this latter point are to be heard in Garikai's decision to eschew professional work in favour of his night delivery work but most poignantly in Nhamo's defiant statement, quoted earlier, that she was not going to pursue her 'duty to be employable' any more:

I looked at my clock and said, 'I am 55. I've been studying all my life', since I got married I never enjoyed my husband, I never enjoyed my children I've been studying, I'm not going to do that I've got the house with the compensation we got from the accident. And I've got a four bedroomed house so I'm sitting pretty with the kids I don't need to struggle any more.

The five stories fit well with the capability approach in that they stress the complex factors that constitute a vision of the good life for these individuals, a vision that is always unique to the individual. They show that pursuit of wellbeing is fallible and aspirations fragile in the face of structural factors and personal tragedy, but also that structure can enable, networks nurture and aspirations be rekindled.

Finally, this paper also serves as a reminder that there is great complexity in the global movements of learners and workers. The literatures of international higher education, employability and migration studies are still in the early stages of becoming better integrated and our research appears to point to the importance of this trend. As far as the international higher education student mobility literature is concerned, our main messages are both of the need to deploy further theoretical resources and the importance of exploring further complexities of type of international higher education student and experience.

\section{References}

Altbach, P. and J. Knight. 2007. "The internationalization of higher education: motivations and realities." Journal of Studies in International Education 11 (3-4): 290-306.

Amazan, R. 2014. "When the diaspora returns: analysis of Ethiopian returnees and the need for highly skilled labour in Ethiopia." In Internationalisation of Higher Education and Global Mobility, edited by B. Streitwieser. Oxford: Symposium.

Appadurai, A. 2004. “The capacity to aspire.” In Culture and Public Action, edited by V. Rao and M. Walton. Stanford: Stanford University Press.

Authors, 2015a. "Communicating employability: the role of communicative competence for Zimbabwean highly skilled migrants in the UK". Journal of International Migration and Integration in press.

Authors, 2015b. "The hidden face of discrimination in the global labour market: the case of Zimbabwean highly skilled migrants in the UK." In People of African Descent and Black Europeans, edited by European Network Against Racism, Brussels: ENAR, in press.

Bonvin, J.-M. and N. Farvaque. 2006. "Promoting capability for work: the role of local actors." In Transforming Unjust Structures, edited by S. Deneulin, M. Nebel, and N. Sagovsky. Dordrecht: Springer.

Bonvin, J.-M. and D. Galster. 2010. "Making them employable or capable? Social integration policies at a crossroads." In Education, Welfare and the Capabilities Approach, edited by H.U. Otto and H. Ziegler. Leverkusen: Barbara Budrich. 
Brooks, R. and J. Waters. 2013. Student Mobilities, Migration and the Internationalisation of Higher Education. Basingstoke: Palgrave Macmillan.

De Jaeghere, J. and A. Baxter. 2014. "Entrepreneurship education for youth in sub-Saharan Africa." Progress in Development Studies 14 (1): 61-76.

de Wit, H. 2002. Internationalization of Higher Education in the United States of America and Europe. Westport: Greenwood.

Gazier, B. and S. Houneman. 1999. "Employability: an evolutionary notion, an interactive concept." In Employability, edited by B. Gazier. Berlin: European Employment Observatory Research Network.

Harvey, W. 2008. "British and Indian expatriate scientists finding jobs in Boston." Global Networks 8 (4): 453-473.

Hillage, J. and E. Pollard 1998. "Employability: developing a framework for policy analysis." London: Research Brief 85, Department for Education and Employment.

Hinchcliffe, G. 2013. "Employability: a capability approach.” In Human Development and Capabilities, edited by A. Boni and M. Walker, M. London: Routledge.

Hollywood, E., V. Egdell, R. McQuaid and D. Michel-Schertges. 2012. "Methodological issues in operationalising the capability approach in empirical research: an example of crosscountry research on youth unemployment in the EU." Social Work and Society 10 (1) [online journal- no overall pagination].

Knight, J. 2004. "Internationalization remodeled: definition, approaches, and rationales." Journal of Studies in International Education 8 (1): 5-31.

Li, Z. 2013. "A critical account of employability construction through the eyes of Chinese postgraduate students in the UK." Journal of Education and Work 26 (5): 473-493.

Luijten-Lub, A., M. Van der Wende and J. Huisman. 2005. “On cooperation and competition: a comparative analysis of national policies for internationalisation of higher education in seven Western European countries." Journal of Studies in International Education 9 (2): 147164.

Massey, D. and K. Espinosa 1997. "What's driving Mexico-U.S. migration?" American Journal of Sociology 102: 939-999.

McGrath, S. and L. Powell. 2015. "Vocational education and training for human development." In Routledge Handbook of International Education and Development, edited by S. McGrath and Q. Gu. London: Routledge. Forthcoming.

McGregor, J. 2008. "Abject spaces, transnational calculations: Zimbabweans in Britain navigating work, class and law." Transactions of the Institute of British Geographers 33: 466-482.

McQuaid, R. and C. Lindsay. 2005. "The concept of employability." Urban Studies 42 (2): 197-219.

Mehtap-Smadi, S. and M. Hashemipour. 2011. "In pursuit of an international education destination: reflections from a university in a small island state." Journal of Studies in International Education 15 (5): 409-430.

Palloni, A., D. Massey, M. Ceballos, K., Espinosa and M. Spittel. 2001. "Social capital and international migration: a test using information on family network." American Journal of Sociology 106: 1262-1298. 
Powell, L. and S. McGrath. 2014. "Advancing life projects: South African students explain why they come to FET colleges." Journal of International and Comparative Education 3 (2): 214-226.

Poros, M. 2001. "The role of migrant networks in linking local labour markets: the case of Asian Indian migration to New York and London." Global Networks 1 (3): 243-260.

Sen, A., 1985. Wellbeing, agency and freedom. The Dewey Lectures 1984. Journal of Philosophy 82 (4): 169-221.

Sen, A., 1992. Inequality Reexamined. Oxford: Oxford University Press.

Sen, A. 2005. "Human rights and capabilities." Journal of Human Development 6 (2): 151166.

Streitwieser. B. (Ed.) 2014. Internationalisation of Higher Education and Global Mobility. Oxford: Symposium.

Vertovec S. 2002. "Transnational networks and skilled labour migration." Transnational Communities Programme, University of Oxford, Working Paper 02/02, available at http://www.transcomm.ox.ac.uk/working\%20papers/WPTC-02-02\%20Vertovec.pdf

Wilkins, S., M. Balakrishnan and J. Huisman. 2012. "Student choice in higher education: motivations for choosing to study at an international branch campus." Journal of Studies in International Education 16 (5): 413-433. 